\title{
TRANSESTERIFICATION OF DEGUMMED PALM OIL (DPO) TO PRODUCE PALM BIODIESEL BY USING LIPOZYME TL IM AS BIOCATALYST
}

\author{
Aira Darusmy, Nur Sri Rahayu, Renita Manurung \\ Departemen Teknik Kimia, Fakultas Teknik, Universitas Sumatera Utara \\ Jalan Almamater,Medan, 20155, Indonesia \\ Email: aira.darusmy@yahoo.com
}

\begin{abstract}
Biodiesel is usually synthesis by transesterification of triglycerides and alcohols in the presence of an acid or an alkaline catalyst but it could produce a chemical waste process. An alternative process is using biocatalyst such as enzyme to synthesis biodiesel that couldn't produce chemical waste process. In this research, the synthesis of biodiesel from degummed palm oil (DPO) and methanol as acyl donor has been investigated with using of Lipozyme as biocatalyst. The purpose of this experiment is to examine the effect of the temperature and the amount of biocatalyst for the synthesis of biodiesel that produced from palm oil and examine the effect of the use of methanol to the lipase enzyme activity in catalyzing the synthesis of biodiesel through transesterification reaction. The variables in this research are the amount of biocatalyst and temperature, and their responses with yield conversion of biodiesel are representated using response surface methodology (RSM) with Minitab software. The reactants and products are analyzed using Gas Chromatography Mass Spectrometry (GCMS). Yield raging from 10$79 \%$ are achieved in 15 hours reaction time. The variable effect of process for obtaining yield can be known from the temperature gives negative result about 0,6738 for the formation of biodiesel product. Afterwards the amount of biocatalyst gives positive result about 22,8091 and interaction between temperature and the amount of biocatalyst give negative result. The results show that the most influential variable is the amount of biocatalyst. Therefore, this experiment would need further investigation works and analysis and reuse of lipozyme as biocatalyst on the run which obtained the highest yield. The highest yield is obtained at a reaction temperature of $45^{\circ} \mathrm{C}$ and the amount of catalyst by $30 \%$. In the reuse of lipozyme, can be repeated four times and obtained the total of the decrease in yield of $77 \%$.
\end{abstract}

Keywords: biodiesel, lipozyme, degummed palm oil (DPO), response surface methodology

\begin{abstract}
Abstrak
Biodiesel umumnya disintesis dengan reaksi transesterifikasi antara trigliserida dan alkohol dengan penambahan katalis asam atau basa sehingga terdapat limbah proses kimia. Proses alternatif lain yaitu dengan menggunakan biokatalis berupa enzim untuk mensintesis biodiesel yang tidak menghasilkan limbah proses kimia. Pada penelitian ini, sintesis biodiesel dari Degummed Palm Oil (DPO) dan metanol sebagai donor asil telah dilakukan dengan menggunakan Lipozyme sebagai biokatalis. Adapun tujuan dari penelitian ini adalah mengkaji pengaruh suhu dan jumlah biokatalis terhadap sintesis biodiesel yang dihasilkan dari DPO serta mengkaji pengaruh penggunaan metanol terhadap aktifitas enzim lipase dalam mengkatalisis sintesis biodiesel melalui reaksi transesterifikasi. Variabel pada penelitian ini adalah jumlah biokatalis dan temperatur, dan responnya terhadap konversi yield pada biodiesel yang disajikan dengan menggunakan metode permukaan respon dengan software Minitab. Reaktan dan produk yang dihasilkan dianalisis dengan menggunakan Gas Chromatography Mass Spectrometry (GCMS). Yield yang diperoleh sebesar 10\% - 79\% dengan waktu reaksi selama 15 jam. Pengaruh variabel terhadap yield dilihat dari suhu reaksi memberikan pengaruh negatif sebesar 0,6738 kali terhadap pembentukan produk biodiesel. Diikuti dengan variabel jumlah biokatalis memberikan pengaruh yang signifikan sebesar 22,8091 kali terhadap pembentukan produk biodiesel. Begitu pula interaksi suhu reaksi dan jumlah biokatalis yang memberikan pengaruh negatif. Sehingga dari hasil analisis yang diperoleh, dapat dikatakan bahwa jumlah biokatalis merupakan faktor yang paling berpengaruh pada sintesis biodiesel. Pada akhirnya, dibutuhkan penelitian yang lebih lanjut mengenai variabel yang berpengaruh pada sintesis biodiesel dan pemakaian ulang lipozyme sebagai biokatalis pada run yang memperoleh yield tertinggi. Yield tertinggi diperoleh pada suhu reaksi $45^{\circ} \mathrm{C}$ dan jumlah katalis sebesar $30 \%$. Pada pemakaian ulang lipozyme, dapat dilakukan pengulangan sebanyak empat kali dan memperoleh total penurunan yield sebesar $77 \%$.
\end{abstract}

Kata kunci: biodiesel, lipozyme, degummed palm oil (DPO), metode permukaan respon 


\section{Introduction}

Transesterification generally using shortchain alcohol with chemical catalyst (acid or alkali) or biocatalyst (enzymatic). Using chemical catalyst in biodiesel production has some disanvantages, they are (1) needs high purity of raw material (FFA less than 2\%) ; (2) can acauses waste water and high cost of product purification ; (3) using chemical catalyst leads to difficulties of catalyst separation after the process [7].

Synthesis of biodiesel using lipase as biocatalyst begins to be developed from the previous researches lately. Lipase as biocatalyst specifically can direct the reaction to the desired product without occurring of the disanvantage by product. Lipase is an enzyme which has the important character in modern biotechnology. There are many industries that applied the using of enzyme as biocatalyst. Lipase is known to have high activity in the hydrolysis reaction and chemical synthesis [8].

The using of enzyme as biocatalyst has a very important part in chemical and pharmaceutical industries. One of the potential biocatalyst is used in some detergent, food, textiles, pulp, paper, and pharmaceutical industries is lipase. The last few years, lipase mostly used as biocatalysts for the hydrolysis reaction or oils and fats synthesis. The main reason is the process that used more efficiently with high selectivity, better quality of product, and eco-friendly. [5]

From some raw materials, which has the prospect to be biodiesel is palm oil and jatropha, but the prospect of palm oil is better for processing massively. As industrial plant, palm oil has spread to almost all parts of Indonesia, the processing technology has been established. Compared with other plants such as soybean, sunflower, and jatropha that still have weaknesses, among others, the source is very limited and still imported [2].

Based on the ideas that have been presented, so the writer wants to use oil of DPO as raw material synthesis of biodiesel with lipozyme as biocatalyst by transesterification with the purpose of obtaining information about the effect of temperature and the large amount of biocatalysts for the synthesis of biodiesel from DPO so that it can be used in an industrial scale later.

\section{Methodology \\ Material and methods}

The main material in this research was CPO, supplied by PT. Perkebunan Nusantara IV Indonesia, methanol and phosphate acid from Merck and Lipozyme TL IM from Sigma Aldrich.

The analysis of fatty acid composition of $\mathrm{CPO}$ as raw material and product as FAME were conducted by using Gas Chromatography (Shimadzu GC 148 by FID detector, DB-5HT column : $1.5 \mathrm{~mm} \times 0.25 \mathrm{~mm}$ ID, thick of film 0.1 $\mu \mathrm{m}$, carrier gas : Helium, flushing gas: nitrogen, oven temperature was $60{ }^{\circ} \mathrm{C}$, injector temperature is $370{ }^{\circ} \mathrm{C}$ and detector temperature is $\left.370{ }^{\circ} \mathrm{C}\right)$.

The content of FFA in CPO were determined using AOCS Official Ca 5a-40 method before and after degumming.

Procedure of transesterification reaction : The DPO reacted with methanol during 15 hours by using shaker velocity $200 \mathrm{rpm}$ in molar ratio 1:3 and temperature $45{ }^{\circ} \mathrm{C}-50{ }^{\circ} \mathrm{C}$ with the amount of biocatalyst is $10-30 \%(\mathrm{w} / \mathrm{w})$ using Erlenmeyer in heater shaker. In this experimental that had the highest yield repeated for three times.

\section{Results and Discussion \\ Analysis of Raw Material of CPO}

In this research, the degummed raw material is analyzed for FFA content that compare before degumming. Fig 1 is a result of CPO analysis before and after degumming.

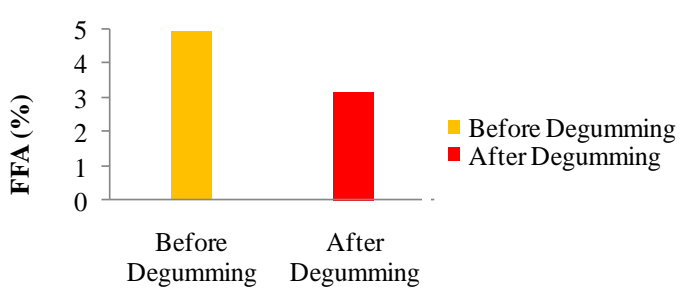

Fig 1. FFA Content of CPO before and after degumming

Fig 1 shows the decreasing of FFA content before and after degumming is about 35,37\%. The decreasing of FFA content means increasing enzyme performance because reducing of content and amount of impurities such as gum that has the potency to plug the pores and decrease the active side of enzyme [3]. Manurung, et al., 2014 had done the research using raw material of $\mathrm{CPO}$ without degumming and acyl acceptor of methanol and the yield biodiesel is about $16,05 \%$, where the obtaining 
of yield is lower than using raw material of degummed palm oil. Based on this condition, the degumming process is a must as pretreatment in using CPO as raw material of biodiesel enzymatic.

Fig 2 shows the fatty acid composition of CPO by using GC.

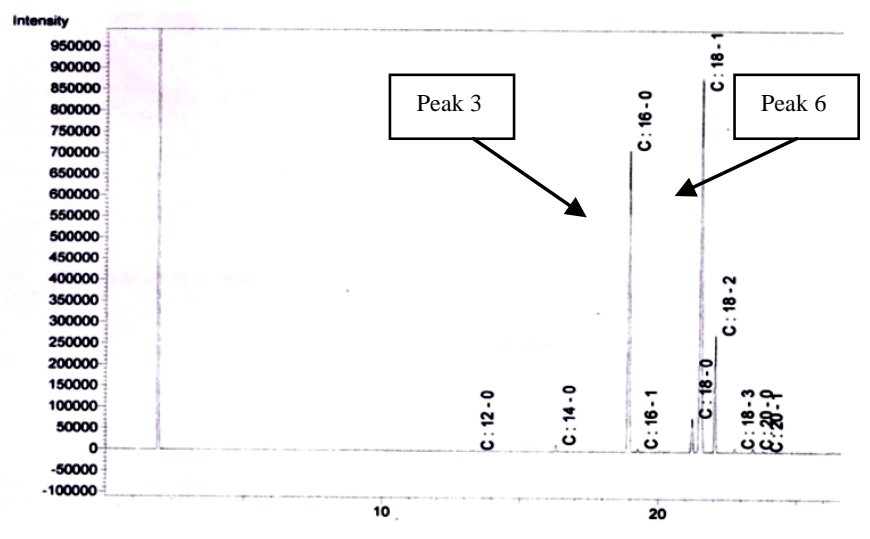

Fig 2. Chromatograph of fatty acid of CPO

Based on an analysis in Fig 2, the fatty acid composition of CPO is shown in table 1.

Table 1. Composition of fatty acid of CPO

\begin{tabular}{|c|c|c|c|}
\hline $\begin{array}{c}\text { No. } \\
\text { of } \\
\text { Peak }\end{array}$ & $\begin{array}{c}\text { Retention } \\
\text { Time } \\
(\text { minute })\end{array}$ & $\begin{array}{c}\text { Ingredient } \\
\text { Component }\end{array}$ & $\begin{array}{c}\text { Composition } \\
\mathbf{\%} \\
(\mathbf{w} / \mathbf{w})\end{array}$ \\
\hline 1 & 13,336 & Lauric Acid $\left(\mathrm{C}_{12: 0}\right)$ & 0,05 \\
\hline 2 & 16,301 & Miristate Acid $\left(\mathrm{C}_{14: 0}\right)$ & 0,51 \\
\hline 3 & 18,952 & Palmitate Acid $\left(\mathrm{C}_{16: 0}\right)$ & 35,03 \\
\hline 4 & 19,255 & Palmitoleic Acid $\left(\mathrm{C}_{16: 1}\right)$ & 0,24 \\
\hline 5 & 21,218 & Stearate Acid $\left(\mathrm{C}_{18: 0}\right)$ & 3,64 \\
\hline 6 & 21,545 & Oleic Acid $\left(\mathrm{C}_{18: 1}\right)$ & 50,03 \\
\hline 7 & 22,043 & Linoleic Acid $\left(\mathrm{C}_{18: 2}\right)$ & 9,77 \\
\hline 8 & 22,749 & Linolenate Acid $\left(\mathrm{C}_{18: 3}\right)$ & 0,31 \\
\hline 9 & 23,418 & Aracidate Acid $\left(\mathrm{C}_{20: 0}\right)$ & 0,32 \\
\hline 10 & 23,783 & Eikocenoic Acid $\left(\mathrm{C}_{20: 1}\right)$ & 0,11 \\
\hline
\end{tabular}

Based on analysis of GC from Fig 2 which the compositions are in Table 1, the dominant component of fatty acid of CPO sample is on peak 6 namely unsaturated fatty acid such as oleic acid for $50.0330 \%(\mathrm{w} / \mathrm{w})$ and on peak 3, namely saturated fatty acid as palmitate acid for $35.0279 \%(\mathrm{w} / \mathrm{w})$.

\section{Analysis of The Effect of The Experimental Variable}

The effect of experimental variable that used and then treated statistically using Minitab software and can be shown in table 2.

Based on the statistic analysis result in table 2, it can be known that the temperature gives negative result about 0,6738 for the formation of biodiesel product. Afterwards the amount of biocatalyst gives positive result about 22,8091 and interaction between temperature and the amount of biocatalyst give negative result. The results show that the most influential variable is the amount of biocatalyst.

Table 2. Estimated of Model Parameter of Statistical Equation

\begin{tabular}{|l|c|}
\hline Term & Coef \\
\hline Constant & 44,6910 \\
\hline Temperature $\left(\mathrm{X}_{1}\right)$ & $-0,6738$ \\
\hline The Amount of Biocatalyst $\left(\mathrm{X}_{2}\right)$ & 22,8091 \\
\hline $\mathrm{X}_{1} * \mathrm{X}_{1}$ & $-6,0210$ \\
\hline $\mathrm{X}_{2} * \mathrm{X}_{2}$ & $-2,2753$ \\
\hline $\mathrm{X}_{1} * \mathrm{X}_{2}$ & $-4,0473$ \\
\hline
\end{tabular}

The Effect of Variable Interaction Between Temperature and The Amount of Biocatalyst

The effect of variable interaction between temperature and the amount of biocatalyst can be shown in Fig 3.

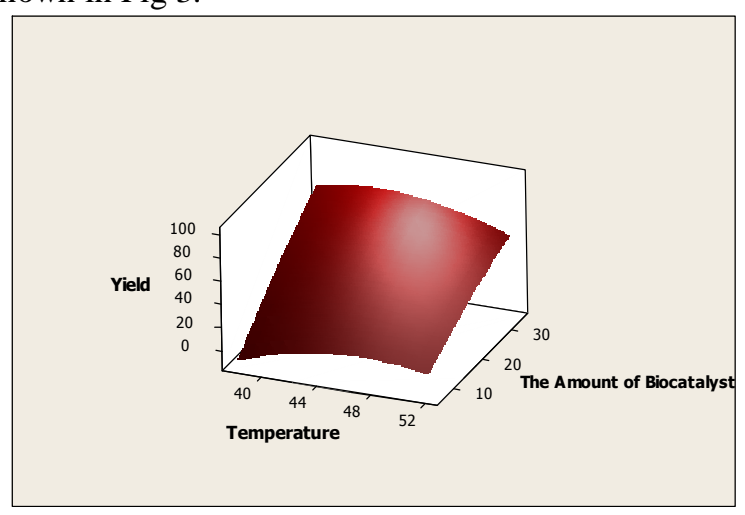

Fig 3. Surface \% Biodiesel Yield for Temperature vs The Amount of Biocatalyst

Fig 3 shows that the increasing of the amount of biocatalyst is more influential in \% yield with a fixed variable reactant mole ratio of $1: 3$ and the surface plot in the addition of biocatalyst can increase significantly. But at the reaction temperature has little effect on $\%$ yield produced even give a negative effect on the yield. 
It's caused by the higher reaction temperature can deactivate lipase. Furthermore, we can see in Fig 4 clearly which variable has more effect on the yield.

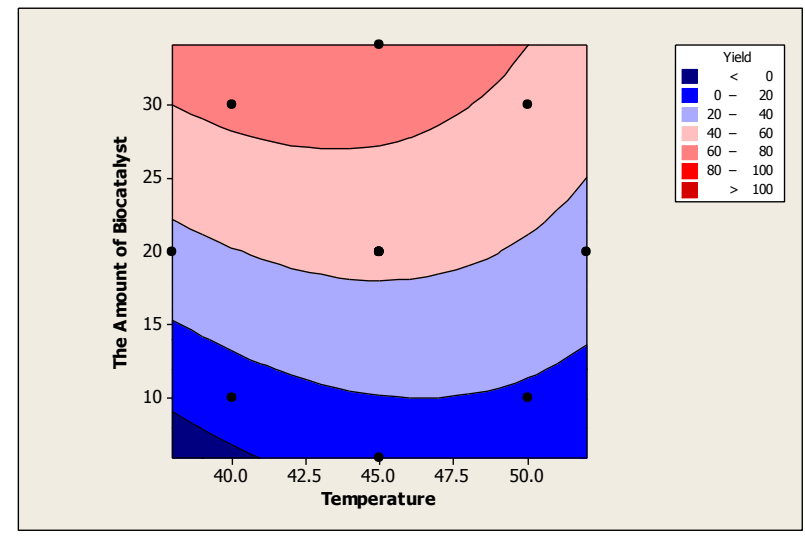

Fig 4. Contour Plot \% Biodiesel Yield for Reaction Temperature vs Amount of Biocatalyst

Fig 4 shows that higher yield can be obtained by adding amount of biocatalyst at low temperature. Reaction temperature gives negative effect, it means that catalyst has good performance at lower temperature [1]. It may be caused by deactivation of lipase at high temperature which can decrease \% biodiesel yield. Contour plot in Figure 4 shows that if reaction temperature maintained $\leq 45{ }^{\circ} \mathrm{C}$ and amount of biocatalyst increased (maximum $30 \%$ ), it can increase \% biodiesel yield. Increasing temperature and mantaining amount of biocatalyst show that there's no effect for yield and even decrease yield.

\section{The Reuse of Lipozyme}

Fig 5 shows the yield obtained by using the reuse of Lipozyme. Fig 5 shows that biodiesel yield decreases from the beginning until the fourth reuse of enzyme. As reported by other researcher, decreasing of enzyme activity may be caused by decreasing of interaction between lipase and substrate, meanwhile reusing enzyme without removing glycerol from the system can inhibit the reaction between substrate and lipase [4]. This research does not use treatment for reusing enzyme and just separate enzyme by using filter paper so it is possible that glycerol left in ezyme to reuse.

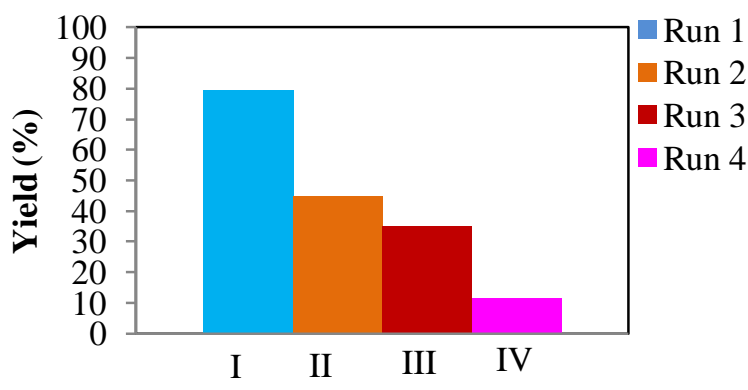

The Reuse of Lipozyme

Fig 5. Relation between Amount of Lipozyme Reuse to Yield of Biodiesel Obtained

Souza et al. (2012), use soybean oil as raw material and ethanol as acyl acceptor with molar ratio $1: 3$ at reaction temperature $50{ }^{\circ} \mathrm{C}$ for 4 hours and amount of biocatalyst $5 \%$, yield of biodiesel obtained about $29 \%$ and yield decreased percentage is $68,97 \%$ with 2 times reuse [6], meanwhile in this research which using methanol as acyl acceptor with molar ratio $1: 3$ at reaction temperature $45{ }^{\circ} \mathrm{C}$ for 15 hours and amount of biocatalyst $30 \%$ obtain biodiesel yield about 79,482 \% with 4 times reuse and the fourth reuse of enzyme obtain biodiesel yield about 11,467, with lower yield decreased percentage about $68,015 \%$.

\section{Analysis of Lypozime Activity}

In this research, analysis of Lipozyme activity that had been done by measuring hydrolyze percentage of DPO which is one of the parameter to measure how much oil hydrolized into fatty acid within specified time. We can see it in Fig 6.

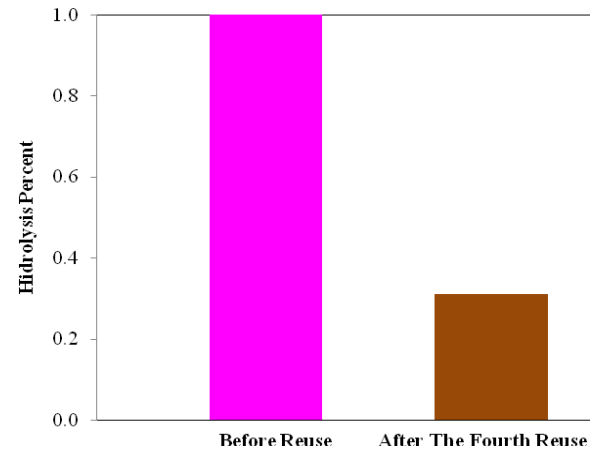

Fig 6. Diagram of Enzyme Activity by Lipozyme Before and After The Forth Reuse 
Fig 6 shows that enzyme activity after the fourth reuse considerably decreased compared with before use, with hydrolysis percentage about $74 \%$.

Enzyme activity decreases significantly in every reuse until the fourth reuse of enzyme because inhibitor blocks the pores of Lipozyme in its active site. One of the inhibitor is accumulated DPO which is unconverted on Lipozyme pores.

\section{Conclusions}

In transesterification of DPO, the most influential variable is the amount of biocatalyst and temperature. Temperature is variable that significantly can't effect when interacted with the other factor. The high yield is obtained at $45{ }^{\circ} \mathrm{C}$ and the amount of biocatalyst at $30 \%$. Yield of biodiesel decreases from the first using of enzyme till the fourth reuse of enzyme. The decreasing of enzyme activity is caused by the interaction between lipase and methanol that attack hydrogen bone of lipozyme. Besides that, the reuse of enzyme without removing glycerol as by product from system in reaction can block the active site of enzyme. In the fourth reuse of enzyme more decrease than the first reuse of enzyme with hidrolysis percentage decrease about $77 \%$.

\section{References}

[1] Bendikiene, Vida, Dovile Sinkuniene, \& Simas Kazlauskas., "Enzymatic Phenethyl Octanoate Synthesis: Lipaseselection and Reaction Optimization By Response Surface Methodology", Journal CHEMIJA, Vol 25, No. 3: 185-194, 2014.

[2] Hermansyah, Heri, Septhian Marno, Rita Arbianti, Tania Surya Utami, dan Anondho Wijanarko., "Interesterifikasi Minyak Kelapa Sawit dengan Metil Asetat untuk Sintesis Biodiesel Menggunakan Candida rugosa Lipase Terimobilisasi", Departemen Teknik Kimia, Fakultas Teknik. Universitas Indonesia, Depok, Vol 8 No. 24-32, 2009.

[3] Manurung, Renita, Ricky Afrianto, \& Melina Widyawati., "Recycleable Of Lipozyme RM IM In Biodiesel Synthesis from $\mathrm{CPO}$ through Interesterification Process", Journal of RSCE, 2014.

[4] Santosh Kumar, "Enzymatic Transesterification of Waste Animal Fats For Production Of Biodiesel”, Dalhousie
University, Halifax, Nova Scotia, Thesis, 2013.

[5] Setyahadi, Siswa, Achmadin Luthfi Machsum, dan Renny S Mokondangan., "Kitin sebagai Penopang untuk Amobilisasi Lipase pada Proses Transesterifikasi Trigliserida", Kedeputian Teknologi Agroindustri dan Bioteknologi, Badan Pengkajian dan Penerapan Teknologi, Jakarta, 2011.

[6] Souza, S.L., Aguieiras, E.C.G \& Langone, M.A.P., "Study of The Commercial Immobilized Lipases Reuse in Biodiesel Synthesis via Transesterification Reactions of Soybean Oil", $11^{\text {th }}$ European Congress on Catalysis, Lyon, France, September $1^{\mathrm{st}}-6 \mathrm{t}^{\mathrm{h}}, 2012$.

[7] Stepani, Florensia Indah., "Produksi Metil Ester dengan Menggunakan Lipase Amobil dari Burkholderia cepacia pada Membran Polyesthersulfone", Program Studi Teknologi Bioproses, Fakultas Teknik. Universitas Indonesia, Depok, Skripsi, 2012

[8] Wulan, Praswasti PDK., Muhammad Titis Rejoso, dan Heri Hermansyah., "Reaksi Hidrolisis Minyak Zaitun Menggunakan Lipase Rhizopus oryzae yang Diammobilisasi Melalui Metode Adsorpsi", Departemen Teknik Kimia, Fakultas Teknik, Universitas Indonesia, Depok, Laporan Penelitian, 2011 